Jurnal Kependudukan Indonesia | Vol. 15 No. 1 Juni 2020|49-58

JURNAL KEPENDUDUKAN INDONESIA

p-ISSN: 1907-2902 (Print)

e-ISSN: 2502-8537 (Online)

\title{
THE EFFECT OF FAMILY LIVING ARRANGEMENT ON DELAYED SEXUAL DEBUT AMONG FEMALE TEENAGERS IN INDONESIA
}

\author{
(PENGARUH PENGATURAN TEMPAT TINGGAL KELUARGA TERHADAP \\ PENUNDAAN HUBUNGAN SEKSUAL PADA REMAJA PEREMPUAN DI \\ INDONESIA)
}

\author{
Anissa Rizkianti*, Ika Saptarini, Siti Masitoh \\ National Institute of Health Research and Development, Ministry of Health \\ *Correspondence: anissarizkianti@gmail.com
}

\begin{abstract}
Abstrak
Penundaan hubungan seksual penting untuk mencegah remaja perempuan dari aktivitas seksual dini, yang dapat menyebabkan mereka rentan terhadap risiko kehamilan yang tidak diinginkan, aborsi yang tidak aman, dan infeksi menular seksual, termasuk HIV. Struktur keluarga berperan penting dalam membentuk perilaku seksual remaja. Namun, isu ini masih kurang dipahami di Indonesia. Penelitian ini bertujuan untuk mengukur hubungan antara pengaturan tempat tinggal keluarga dan penundaan hubungan seksual pada remaja perempuan Indonesia. Kajian ini menganalisis data responden perempuan berusia 19-24 tahun pada Survei Demografi dan Kesehatan Indonesia (SDKI) 2017, dengan menggunakan statistik deskriptif dan regresi logistik multivariat. Setelah mengontrol jenis kelamin kepala rumah tangga, status pendidikan dan pengetahuan tentang HIV/AIDS, kajian ini menemukan bahwa remaja perempuan yang tinggal serumah dengan kedua orang tua cenderung untuk menunda hubungan seksual, meskipun pengaruh ini tidak signifikan. Pengaturan tempat tinggal keluarga memiliki konsekuensi penting dalam hal perkembangan seksual pada remaja perempuan. Intervensi untuk memperkuat dukungan dalam keluarga dan perbaikan hubungan orang tua dan remaja sangat penting dalam mengurangi kerentanan remaja terhadap perilaku seksual berisiko.
\end{abstract}

Kata kunci: pengaturan tempat tinggal, hubungan seksual, seks pranikah, remaja perempuan, Indonesia

\begin{abstract}
Delaying sexual debut is essential to prevent female teenagers from early sexual activity that can expose them to the risks of unintended pregnancy, unsafe abortion, and sexually transmitted infections, including HIV. Family structure has a critical role in shaping adolescents' sexual behaviors. However, this issue remains poorly understood in Indonesia. The study aims to assess the association between family living arrangement and delayed sexual debut among Indonesian female youth. The study analyzed data of unmarried Indonesian adolescents age 19-24 from Indonesia Demographic and Health Survey (DHS) 2017, using descriptive statistics and multivariate logistic regression. After controlling for sex of household head, educational status and knowledge of HIV/AIDS, female teenagers who lived with both parents were more likely to postpone sexual intercourse; however, this effect was not statistically significant. The family living arrangement has important consequences in terms of sexual development among female teenagers. Interventions on strengthening supportive atmosphere within the family and improving parent-adolescent relationships are critical in reducing teenagers' vulnerability to sexual risk-taking behaviors.
\end{abstract}

Keywords: living arrangement, sexual debut, premarital sex, female teenager, Indonesia 
Jurnal Kependudukan Indonesia | Vol. 15, No. 1, Juni 2020 | 49-58

\section{INTRODUCTION}

Adolescence is a critical developmental period in which major physical, as well as psychological developments, occur. It is the stage that involves the appearance of sexual and reproductive maturity, along with the transition of critical thought and attitudes toward sexuality (Kar et al., 2015). Adolescence is also typically a period of experimentation, new experiences, and vulnerability, which places them at a greater risk of early sexual debut (Idele et al., 2014). Although there is no universal definition of early sexual debut, it is often classified as sexual intercourse initiated before the ages of 14-16 years (Kastbom et al., 2015; Madkour et al., 2010a; Pettifor et al., 2009; Stöckl et al., 2013). In lowand middle-income countries (LMICs), early sexual intercourse is more common than in other parts of the world. Evidence shows that the median age at first sex among 20-24-year-old women in Sub-Saharan Africa ranges from a low of 15 to a high of 19 years (Hindin \& Fatusi, 2009; Idele et al., 2014). Other studies show even older median ages of first sex such as Latin America and the Caribbean, where 50\% of young women engage in premarital sex between 18 and 19 (Hindin \& Fatusi, 2009). However, premarital sex seems to be less in Asia than in other LMICs (Noroozi et al., 2014). In Indonesia, the age of sexual debut is quite young, especially for girls. About $1 \%$ of boys and $4 \%$ of girls have reportedly had first sexual intercourse before 13 years, some as young as before ten. A third of 17 years old adolescents in Indonesia have had at least one sexual intercourse (Departemen Kesehatan, 2010).

Sexual activity at an early age of adolescence can expose young people to negative health outcomes. An increasing proportion of young women engaging in premarital sexual activity can expose them to unwanted pregnancy and unsafe abortion (Hindin \& Fatusi, 2009; Madkour et al., 2010b; Salih et al., 2015). Also, the outcomes related to early sexual activity among teenagers are often complex. Young women who initiate sexual activity at an earlier age are likely to have sex with more partners and put them at risk of sexually transmitted infections (STIs) exposure, including HIV (Hindin \& Fatusi, 2009; Oladepo \& Fayemi, 2011). Based on UNAIDS data, adolescents and young people face a disproportionally high risk of HIV infection. Each day, half a million young people, mostly young women, are infected with an STI (Noroozi et al., 2014).
In 2017, more than 4,000 adolescent boys and 2,500 adolescent girls between the ages of 15-19 in Indonesia were newly infected with HIV (UNICEF, 2018).

For such reasons, initiatives to delay sexual debut have been considered an important component of sexual and reproductive health (SRH) intervention program for teenagers. Sexual abstinence is a protective barrier that can reduce undesirable sex at an earlier age. Nevertheless, young people seem to lack the necessary knowledge and information on the consequences of premarital sex; hence they need to be encouraged to postpone sexual intercourse and help them face the burden to become sexually active before they are ready (Savi-Çakar et al., 2015). The family is an important factor that may provide emotional support in teenagers and shape teenagers' sexual behavior. Parents' engagement and communication are important to adolescents' development of sexual values and attitudes (Noller \& Atkin, 2014). In addition, various studies have also shown the relation of family structure and living arrangement on delayed sexual initiation (Pilgrim et al., 2014; Somefun \& Odimegwu, 2018; Stark et al., 2016; Tenkorang \& Adjei, 2015).

In Indonesia, a family is influenced by traditional cultural values that determine family members' roles (Riany et al., 2017) and pertain to family structure, function, and attitudes. Family structure generally represents the relationship between biological kinship, marital status, and living arrangement (Pasley \& Petren, 2015). Moreover, the measures of family structure capture parent-child's relationships in the household. One of the key aspects of family structure is living arrangement. The existing literature considers children's co-residence with parents' changes over the life cycle (Wiemers et al., 2017) and may influence the timing of sexual debut (Tenkorang \& Adjei, 2015). However, the effect of family living arrangement on adolescents' sexual initiation remains understudied in Indonesia. Using data from a nationally-representative survey, we examined the relationship between family living arrangement and sexual debut among Indonesian female youth. We hypothesized that female teenagers who live with both parents, which may be more likely to gain support and companionship, are less likely to engage in early sexual activity. 


\section{METHOD}

We used a cross-sectional design of secondary data from the Indonesia Demographic and Health Survey (DHS) 2017, which is publicly available on the DHS website. The Indonesia DHS is a nationally representative survey, aiming to generate comprehensive information about demographics, maternal and child health in Indonesia. Statistics Indonesia conducted data collection in collaboration with the National Family Planning Board, Ministry of Health and ICF International, Calverton, MD, USA (BKKBN, BPS, Kemenkes, \& ICF, 2018a). We assessed the relationship of family living arrangement and onset of first sexual intercourse from the Adolescent Reproductive Health (ARH) component of the Indonesia DHS 2017, which focused on male and female youth 15-24 years old. The sampling technique of this survey employed two-stage cluster sampling in which census blocks were selected using systematic random sampling as the primary sampling unit, followed by a random selection of 25 households. Further details of the sampling design are available in the Indonesia DHS 2017 preliminary report (BKKBN, BPS, Kemenkes, \& ICF, 2018b).

Of the 49,261 households targeted in this survey, 48,261 households were found, and 47,963 or $99 \%$ of the households were successfully interviewed. In the interviewed households, 11,032 never-married women age 15-24 were eligible for interview, of which 10,691 were completely interviewed, yielding a response rate of $97 \%$ (BKKBN, BPS, Kemenkes, \& ICF, 2018a). For this analysis, we only selected all individual data of unmarried female youth aged 19-24, making a weighted total sample of 3,943. This study was restricted to females because of their augmented sexual and reproductive health risks.

Our primary dependent variable, delayed sexual debut, refers to the decision to delay or postpone the initiation of sexual activity for a certain period. It was defined as age at first sexual intercourse and measured as a binary outcome, derived from the information about first sexual intercourse after 18 years old. As we are interested in adolescents who delayed sexual debut, those who delayed sex were coded as "1". In contrast, sexual debut at 18 years or younger was coded as "0" and defined as the early sexual debut. This cut-off was used as the average age of young Indonesian women to have early sexual intercourse is 19 years old (Nuraliah et al., 2018). Respondents who have never had sex were included in the analysis and coded as " 1 " to represent the entire population of interest and reduce the potential of selection bias.

The main independent variable is the family living arrangement, measured by two binary variables, classified as "living with no parent or single parent" and "living with both parents". This variable was measured using data of adolescents aged 15-24 from the Women Recode (IR file) and merging with the Household Member Recode (PR file). As no data of parental survival were available, we used the information about the relationship with the head of the household to construct the family living arrangement. Further disaggregation to identify the specific parent (mother or father) would have been informative, but this was not possible due to small numbers in some categories in the variable.

Other explanatory variables included sex of household head, educational status, household wealth index, exposure to mass media, knowledge of human immunodeficiency virus/acquired immunodeficiency syndrome (HIV/AIDS), and place of residence measured as rural and urban. Educational status was classified into three categories: primary or less if respondent completed junior high school or less; secondary if respondent completed senior high or technical school; and higher if respondent completed at least college degree. Wealth index is a proxy of household socioeconomic status and calculated using data on a household's ownership of selected assets, including consumer items and dwelling characteristics. Mass media exposure was measured using questions on how often respondents read newspapers or magazines, listen to the radio and watch television weekly. Responses were coded as " 0 " for respondents who were not exposed to any types of media; " 1 " for respondents who were exposed less than once a week; and " 2 " for respondents who were exposed at least once a week. Respondents who accessed one of all three media (newspapers, magazines, television, or internet) at least once a week were considered those exposed to mass media. Information on knowledge of HIV/AIDS was 
derived from the question of whether respondents have ever heard of HIV/AIDS.

For statistical analysis, cross-tabulation for all explanatory variables with the sexual debut was conducted to display the distribution of the adolescents' sexual debut by sociodemographic characteristics and other independent variables, and to assess the relationship by using the chi-square test with the significance level $(\alpha)$ of 0.05 . A logistic regression model was fitted to examine the degree of the risk of attributes to each factor and to control possible intervening variables. All statistically significant variables at $\mathrm{p}<0.25$ and potential confounders were retained in the model. Considering the sample design and response rate, we used sample weights to adjust for differences in the probability of selection between respondents. Where information was missing, or respondents did not know, the general rule for DHS data processing was followed, and the missing value was thereby assigned. The adjusted odds ratios (ORs) and two-sided 95\% confidence intervals were reported. Statistical analysis was performed using Stata/SE version 15 (StataCorp, 2017).

The 2017 IDHS followed the standard DHS survey protocol and data collection procedures approved by the Institutional Review Board of ICF International and ORC Macro (ICF IRB FWA00000845). They also ensure that the survey adheres to the U.S. Department of Health and Human Services requirement for the protection of human subjects, ensuring data anonymity and guarantees the confidentiality of all participants, while Indonesia ensures that the survey follows local laws and norms.

\section{RESULTS}

By eliminating missing cases, total samples covered in this study are 3,943 unmarried female youth aged 1924. Table 1 displays the distribution of sexual debut by family living arrangement and other background characteristics. By family living arrangement, the majority of female teenagers both living with no parent or one parent and living with both parents have never had premarital sex or postpone their sexual debut, $98.3 \%$, and $98.9 \%$, respectively. Girls who live with male headed-households were more likely (99\%) to have premarital sex than those who live with femaleheaded household $(98.5 \%)$. Female teenagers with a higher level of education had a greater proportion of delayed sexual debut than those who completed primary or secondary school. The proportion of delayed sexual debut tends to be higher among adolescents who came from higher-income households, lived in urban areas, had been exposed to mass media, and had knowledge of HIV/AIDS.

The results presented in Table 2 show the result of multivariate analysis between family living arrangement and delayed sexual debut, after adjusting for sex of household head, educational status, and knowledge of HIV/AIDS. Household wealth index was omitted from the multivariate model due to high collinearity with education. As can be seen from the table, family living arrangement did not significantly affect sexual debut among female teenagers. However, it was shown that the odds of having late sexual debut are higher for female adolescents living with both parents than those who lived with no parent/single parent (AOR=1.33; 95\% CI: 0.47-3.78). In addition, only educational status was found to be significant in the model. Girls who completed higher education (AOR=6.02; 95\% CI: 1.42-25.5) had higher odds of delaying sexual debut compared to their counterparts. 
The Effect of Family Living Arrangement on ... | Anissa Rizkianti dkk.

Tabel 1. Distribution of sexual debut among female youth by background characteristics, Indonesia DHS 2017

\begin{tabular}{|c|c|c|c|c|}
\hline \multirow[t]{2}{*}{ Characteristics } & \multicolumn{2}{|c|}{$\begin{array}{l}\text { Early sexual debut } \\
\text { (sex at or befor } 18 \text { ) }\end{array}$} & \multicolumn{2}{|c|}{$\begin{array}{c}\text { Delayed sexual debut } \\
\text { (sex after 18) }\end{array}$} \\
\hline & $\mathbf{N}$ & $\%$ & $\mathbf{N}$ & $\%$ \\
\hline \multicolumn{5}{|l|}{ Family living arrangement } \\
\hline Living with no parent/single parent & 11 & 1.7 & 652 & 98.3 \\
\hline Living with both parents & 36 & 1.1 & 3,244 & 98.9 \\
\hline \multicolumn{5}{|l|}{ Educational status } \\
\hline Primary or less & 9 & 5.5 & 371 & 94.5 \\
\hline Secondary & 27 & 1.5 & 6,837 & 98.5 \\
\hline Higher & 11 & 0.5 & 2,329 & 99.5 \\
\hline \multicolumn{5}{|l|}{ Sex of household head } \\
\hline Male & 41 & 1.2 & 3,398 & 98.8 \\
\hline Female & 6 & 1.2 & 498 & 98.8 \\
\hline \multicolumn{5}{|l|}{ Household wealth index } \\
\hline Poorest & 19 & 3.5 & 530 & 96.5 \\
\hline Poorer & 7 & 1.1 & 642 & 98.9 \\
\hline Middle & 2 & 0.3 & 690 & 99.7 \\
\hline Richer & 10 & 1.1 & 892 & 98.9 \\
\hline Richest & 9 & 0.8 & 1,142 & 99.2 \\
\hline \multicolumn{5}{|l|}{ Place of residence } \\
\hline Rural & 21 & 1.4 & 1,455 & 98.6 \\
\hline Urban & 26 & 1.0 & 2,441 & 99.0 \\
\hline \multicolumn{5}{|l|}{ Exposure to mass media } \\
\hline No & 24 & 1.8 & 1,343 & 98.2 \\
\hline Yes & 23 & 0.9 & 2,553 & 99.1 \\
\hline \multicolumn{5}{|l|}{ Knowledge on HIV/AIDS } \\
\hline No & 11 & 5.1 & 205 & 94.9 \\
\hline Yes & 36 & 1.0 & 3,691 & 99.0 \\
\hline
\end{tabular}

Tabel 2. Distribution of sexual debut among female youth by background characteristics, Indonesia DHS 2017

\begin{tabular}{|c|c|c|c|c|}
\hline Variables & Crude OR & $95 \% \mathrm{CI}$ & Adjusted OR & $95 \% \mathrm{CI}$ \\
\hline \multicolumn{5}{|l|}{ Family living arrangement } \\
\hline Living with no parent/single parent & Ref. & & Ref. & \\
\hline Living with both parents & 1.01 & $0.41-2.48$ & 1.33 & $0.47-3.78$ \\
\hline \multicolumn{5}{|l|}{ Sex of household head } \\
\hline Male & Ref. & & Ref. & \\
\hline Female & 1.22 & $0.37-4.02$ & 1.70 & $0.37-7.75$ \\
\hline \multicolumn{5}{|l|}{ Educational status } \\
\hline Primary or less & Ref. & & Ref. & \\
\hline Secondary & $4.67^{* * * *}$ & $1.97-11.10$ & 2.79 & $0.86-9.12$ \\
\hline Higher & $10.85^{* * *}$ & $3.43-34.4$ & $6.02^{* *}$ & $1.42-25.5$ \\
\hline \multicolumn{5}{|l|}{ Household wealth index } \\
\hline Poorest & Ref. & & \multirow{5}{*}{\multicolumn{2}{|c|}{ N/A ${ }^{1}$}} \\
\hline Poorer & $4.48^{* * * *}$ & $1.45-13.83$ & & \\
\hline Middle & $17.31^{* * *}$ & $3.36-89.10$ & & \\
\hline Richer & $3.95^{* * *}$ & $1.60-9.76$ & & \\
\hline Richest & $5.25^{* * *}$ & $1.89-14.59$ & & \\
\hline \multicolumn{5}{|l|}{ Place of residence } \\
\hline Rural & Ref. & & \multicolumn{2}{|c|}{ N/A ${ }^{1}$} \\
\hline Urban & 1.34 & $0.66-2.72$ & & \\
\hline \multicolumn{5}{|l|}{ Exposure to mass media ${ }^{2}$} \\
\hline No & Ref. & & \multicolumn{2}{|c|}{ N/A ${ }^{1}$} \\
\hline Yes & 1.46 & $0.72-2.99$ & & \\
\hline \multicolumn{5}{|l|}{ Knowledge on HIV/AIDS } \\
\hline No & Ref. & & Ref. & \\
\hline Yes & $5.73^{* * *}$ & $2.54-12.92$ & 2.60 & $0.84-8.07$ \\
\hline
\end{tabular}

$* * * P<0.001, * * P<0.05, * P<0.1$; the multivariate model was adjusted for the sex of household head, educational status, and knowledge on HIV/AIDS; sex of household head is considered as a potential confounder, so it retained from the model.

${ }^{1}$ Household wealth index was excluded from the multivariate model because of high collinearity with education. Place of residence and exposure to mass media were not statistically significant in the univariate analysis, so they are omitted from the model. 
Jurnal Kependudukan Indonesia | Vol. 15, No. 1, Juni 2020 | 49-58

\section{DISCUSSION}

Our findings above illustrate that female adolescent who live with both parents had higher odds of delaying sexual debut, although results were not significant. Similar results were seen from a study in Africa (Somefun \& Odimegwu, 2018). Many scholars hold the view that family has a strong influence on adolescent's sexual behavior. Research in Sierra Leone, for example, shows the protective effect of living with a surviving biological parent to delay early sexual debut (Stark et al., 2016). Other studies in Africa noted that early sexual debut was positively associated with living with one biological parent (Pilgrim et al., 2014; Shoko et al., 2018; Wamoyi et al., 2015). Biological parents have been seen as primary caregivers who provide care and guidance to their children through parent-child relationships and parental supervision. Moreover, research has shown that adolescents living with two biological parents are more likely to have a better quality of parent-adolescent relationships as their parents are more supportive and communicative (Hoskins, 2014).

The increased probability of delaying sexual debut among teenagers living with both parents' supports can be explained by the fact that female teenagers may be closer with family members compared to males, put more meaning on the family relationships and consequently more affected by changes and disruption in family structure (Mmari et al., 2016). Some research suggests that girls with absent fathers are susceptible to having unstable and conflicted parental relationships, which correspondingly influence accelerated pubertal maturation (Mendle et al., 2009). The family environment, therefore, can be a strong source of support for providing close relationships, creating good communication, and modeling positive behaviors among adolescents. In a good family environment is provided, teenagers can gain higher self-esteem and better problem-solving skills as they engage in positive communication with their parents. In contrast, teenagers living with a less secure family environment seem to use ineffective coping strategies, for example, engaging in risky behaviors (Noller \& Atkin, 2014).

The current study further demonstrated that sex of household head, educational status, and knowledge of HIV/AIDS have a positive relationship with delayed sexual debut among female teenagers, although the relationships remained insignificant. These results matched those observed in earlier studies. In Latin America, adolescents living in a male-headed household increases the risk of sexual debut (Duryea et al., 2003). Similarly, more South African female youth living in a female-headed household have late sexual experience compared to female youth living in maleheaded households (Baruwa \& Amoateng, 2019). However, no statistically significant relationship was observed between sexual debut and gender of household heads. It has been argued that girls tend to be much closer to the female household head than the male counterpart. This pattern could be due to a lack of information and communication about sexual reproductive health (SRH) from the father as the head of households. In contrast, while female household heads may easily discuss SRH issues with teenage girls, meaning that the likelihood of early sexual activity will be reduced (Tuyiragize et al., 2018).

Although this study failed to demonstrate any significant relationship in delaying sexual intercourse between female teenagers living with both parents than those living with no parent or one parent, education attainment appears to be positively related to delayed sexual debut among female teenagers. Female adolescents with better education are less likely to initiate early sexual intercourse due to adequate information and knowledge about SRH needs and rights provided by education (Baruwa \& Amoateng, 2019). Moreover, recent evidence suggests that universal access to education may help delay the timing of sexual debut (Shoko et al., 2018) and recognizes the importance of sex education programs at middle school youth that reduces sexual risk-taking behavior.

Another important finding was that having knowledge of HIV/AIDS increased the likelihood of delaying sexual debut. However, no significant difference in this likelihood was found compared with those who did not have any knowledge of HIV/AIDS. The lack of significance between the knowledge of HIV and engagement in risky sexual behaviors and practices among adolescents may be a result of the complex interplay of other factors that can affect sexuality, such as culture and family setting (Ajide \& Balogun, 2018). This view was supported by a study in Nigeria that found that major reasons for the sex abstinence among 
unmarried girls include the fear of pregnancy, STIs, and traditional norms that do not support premarital sex (Oladepo \& Fayemi, 2011).

As pointed above, our results reinforce the importance of considering the impact of parental absence on young women's sexual risk-taking behavior. The attitudes of parents about sexual behavior may affect the acceptability of premarital sex among adolescents. Intercourse before marriage is considered a moral issue in Indonesia's socio-cultural norms (Berliana et al., 2018). The 2017 IDHS reported that $4 \%$ of nevermarried men and $1 \%$ of never-married women age 15 19 had sexual intercourse before marriage (BKKBN, BPS, Kemenkes, \& ICF, 2018a). It is deviant behavior in Indonesian culture and associated with poor communication and a less positive family atmosphere (Berliana et al., 2018).

There is a need, therefore, to undertake family-based prevention programs that target developing better support and connectedness between family and teenagers, by creating an appropriate environment and incorporating family in teenagers' sexual decisionmaking (Ismayilova et al., 2012). Family support needs to be enhanced by providing socialization programs for parents of adolescents and encouraging them to be more open to discussing their children's SRH issues, including their risk-taking behaviors. Community health workers and health professionals may provide socialization meetings for teenagers and parents regularly, disseminate information through social networks, and conduct peer educator training in school by building collaboration between parents, school and health workers in the public health centers (Puskesmas) through Adolescent Healthcare Service Program or Program Pelayanan Kesehatan Remaja (PKPR) (Violita \& Hadi, 2019). Strong support and more trust from teachers are more likely to motivate parents to familiarize themselves with SRH program (Igor et al., 2015).

Moreover, interventions must address factors within the family setting, where the research is limited. Further research is needed to examine the effect of family support and parent-adolescent relationships on sexual risk-taking behavior. Finally, it is important to explore and understand cultural and contextual factors, such as gender norms, intergenerational tradition, and family values. Parenting styles may be different across all ethnic groups in Indonesia. Hence, much work remains to be done that focuses on ethnically diverse groups to gain a more in-depth understanding of how cultural meanings of specific ethnic groups influence adolescent risky outcomes and behaviors.

However, this study's overall design is a major limitation in our ability to make causal inferences about how family living arrangement contributes to change in early sexual behavior among female teenagers. Furthermore, under-reporting might be a possibility due to the sensitive nature of questions related to sexual behaviors. Additionally, we did not have information on parental survival, which may itself explain the distinct role of mother and father co-resident in adolescents' sexual behavior independently. Less emphasis was also not given to more explore paternal variables, which limit our understanding of which paternal factors are most influential in modifying this behavior. Despite these limitations, our study provides evidence to support the role of the family as an important correlate of teenagers' sexual behavior, which may represent a critical missed opportunity to improve the SRH of young people in Indonesia.

\section{CONCLUSION}

Our findings above illustrate that no significant difference in sexual debut was found between female teenagers who lived with both parents and those who lived with one parent/single parent. Nevertheless, family living arrangement has important consequences in terms of sexual behavior among female teenagers. This statement has important implications, especially since many Indonesian young females demand to value their family so much. Interventions on strengthening supportive environment within the family and improving connectedness are critical in reducing teenagers' vulnerability to sexual risk-taking behaviors. Given that contextual factors influence the relationship between family living arrangement and risky behaviors among adolescents, intervention programs should also focus on family, adolescents, and the community context through community-based parenting support. 


\section{DAFTAR PUSTAKA}

Ajide, K. B., \& Balogun, F. M. (2018). Knowledge of HIV and intention to engage in risky sexual behaviour and practices among senior school adolescents in Ibadan, Nigeria. Archives of Basic and Applied Medicine, 6(1), 3-8. https://www.ncbi.nlm.nih.gov/pmc/articles/P MC6169801/

Baruwa, O. J., \& Amoateng, A. Y. (2019). Sociodemographic factors associated with early sexual experience among South African female youth. Research Square. https://doi.org/10.21203/rs.2.15891/v1

Berliana, S. M., Utami, E. D., Efendi, F., \& Kurniati, A. (2018). Premarital sex initiation and the time interval to first marriage among Indonesians. Bulletin of Indonesian Economic Studies, 54(2), 215-232. https://doi.org/10.1080/ 00074918.2018 .1440067

BKKBN [National Population and Family Planning Board], BPS [Statistics Indonesia], Kemenkes [Ministry of Health], \& ICF. (2018a). Indonesia demographic and health survey 2017: Adolescent reproductive health. BKKBN, BPS, Kemenkes, and ICF.

(2018b) Indonesia demographic and health survey 2017. https://dhsprogram.com/publications/publicati on-fr342-dhs-final-reports.cfm

Departemen Kesehatan. (2010). Laporan riset kesehatan dasar (RISKESDAS) 2010. Departemen Kesehatan Republik Indonesia.

Duryea, S., Edwards, A. C., \& Ureta, M. (2003). Critical decisions at a critical age: Adolescents and young adults in Latin America. InterAmerican Development Bank.

Hindin, M. J., \& Fatusi, A. O. (2009). Adolescent sexual and reproductive health in developing countries: An overview of trends and interventions. International Perspectives on Sexual and Reproductive Health, 35(2), 58-62. https://doi.org/10.1363/3505809

Hoskins, D. H. (2014). Consequences of parenting on adolescent outcomes. Societies, 4(3), 506-531. https://doi.org/10.3390/soc4030506
Idele, P., Gillespie, A., Porth, T., Suzuki, C., Mahy, M., Kasedde, S., \& Luo, C. (2014). Epidemiology of HIV and AIDS among adolescents: Current status, inequities, and data gaps. Journal of Acquired Immune Deficiency Syndromes, 66(Suppl. 2), 144-153. https://doi.org/ 10.1097/QAI.000000000000017

Igor, K., Ines, E., \& Aleksandar, Š. (2015). Parents' attitudes about school-based sex education in Croatia. Sexuality Research and Social Policy, 12, 323-345. https://doi.org/10.1007/s13178015-0203-Z

Ismayilova, L., Ssewamala, F. M., \& Karimli, L. (2012). Family support as a mediator of change in sexual risk-taking attitudes among orphaned adolescents in rural Uganda. Journal of Adolescent Health, 50(3), 228-235. https:// doi.org/10.1016/j.jadohealth.2011.06.008

Kar, S. K., Choudhury, A., \& Singh, A. P. (2015). Understanding normal development of adolescent sexuality: A bumpy ride. Journal of Human Reproductive Sciences, 8(2), 70-74. https://doi.org/10.4103/0974-1208.158594

Kastbom, Å. A., Sydsjö, G., Bladh, M., Priebe, G., \& Svedin, C. G. (2015). Sexual debut before the age of 14 leads to poorer psychosocial health and risky behaviour in later life. Acta Paediatrica, International Journal of Paediatrics, 104(1), 91-100. https://doi.org/10.1111/apa.12803

Madkour, A. S., Farhat, T., Halpern, C. T., Godeau, E., \& Gabhainn, S. N. (2010a). Early adolescent sexual initiation as a problem behavior: A comparative study of five nations. Journal of Adolescent Health, 47(4), 389-398. https:// doi.org/10.1016/j.jadohealth.2010.02.008

(2010b). Early adolescent sexual initiation and physical/psychological symptoms: A comparative analysis of five nations. Journal of Youth and Adolescence, 39(10), 1211-1225. https://doi.org/10.1007/s10964-010-9521-x

Mmari, K., Kalamar, A. M., Brahmbhatt, H., \& Venables, E. (2016). The influence of the family on adolescent sexual experience: A comparison between Baltimore and Johannesburg. PLoS One, 1-14. https://doi.org/10.1371/journal.pone.0166032 
Noller, P., \& Atkin, S. (2014). Family life in adolescence. De Gruyter Open Ltd.

Noroozi, M., Taleghani, F., Merghati-Khoei, E. S., Tavakoli, M., \& Gholami, A. (2014). Premarital sexual relationships: Explanation of the actions and functions of family. Iranian Journal of Nursing and Midwifery Research, 19(4), 424-431. https://www.ncbi.nlm.nih.gov/ pmc/articles/PMC4145500/

Nuraliah, N., Wahab, A., \& Emilia, O. (2018). Usia saat menarche dan usia pertama kali hubungan seksual pranikah wanita dewasa muda di Indonesia: Analisis data SDKI 2003-2012. Berita Kedokteran Masyarakat, 34(5), 10-14. https://doi.org/10.22146/bkm.37720

Oladepo, O., \& Fayemi, M. M. (2011). Perceptions about sexual abstinence and knowledge of HIV/AIDS prevention among in-school adolescents in a western Nigerian city. BMC Public Health, 11(1), 304. https://doi.org/10.1186/1471-2458-11-304

Pasley, K., \& Petren, R. E. (2015). Family structure. In C. L. Shehan (Ed.) Encyclopedia of family studies (pp. 1-4). https://doi.org/10.1002/ 9781119085621.wbefs016

Pettifor, A., O’Brien, K., Macphail, C., Miller, W. C., \& Rees, H. (2009). Early coital debut and associated HIV risk factors among young women and men in South Africa. International Perspectives on Sexual and Reproductive Health, 35(2), 82-90. https://doi.org/10.1363/ifpp.35.082.09

Pilgrim, N. A., Ahmed, S., Gray, R. H., Sekasanvu, J., Lutalo, T., Nalugoda, F., Serwadda, D., \& Wawer, M. J. (2014). Family structure effects on early sexual debut among adolescent girls in Rakai, Uganda. Vulnerable Children and Youth Studies, 9(3), 193-205. https://doi.org/10.1080/17450128.2013.84202 7

Riany, Y. E., Meredith, P., \& Cuskelly, M. (2017). Understanding the influence of traditional cultural values on Indonesian parenting. Marriage and Family Review, 26(12), 35593571. https://doi.org/10.1080/01494929.2016. 1157561

Salih, N. A., Metaferia, H., Reda, A. A., \& Biadgilign, S. (2015). Premarital sexual activity among unmarried adolescents in northern Ethiopia: A cross-sectional study. Sexual and Reproductive Healthcare, 6(1), 9-13. https://doi.org/10.1016/j.srhc.2014.06.004
Savi-Çakar, F., Tagay, Ö., \& Ikiz, F. E. (2015). Risky behaviors of adolescents: Definitions and prevention. In A. M. Columbus (Ed.), Advances in Psychology Research. Nova Science Publishers, Inc.

Shoko, M., Ibisomi, L., Levin, J., \& Ginsburg, C. (2018). Relationship between orphanhood status, living arrangements and sexual debut: Evidence from females in middle adolescence in Southern Africa. Journal of Biosocial Science, 50(3), 380-396. https://doi.org/10.1017/S0021932017000475

Somefun, O. D., \& Odimegwu, C. (2018). The protective role of family structure for adolescent development in sub-Saharan Africa. PloS One, 13(10), 1-15. https://doi.org/10.1371/journal.pone.0206197

Stark, L., Tan, T. M., Muldoon, K. A., King, D., Lamin, F. M., Lilley, S., \& Wessells, M. G. (2016). Family structure and sexual and reproductive health outcomes among adolescents in rural Sierra Leone. Global Public Health, 11(3), 309-321. https://doi.org/10.1080/17441692. 2015.1031155

StataCorp. (2017). Stata statistical software: Release 15. StataCorp LP.

Stöckl, H., Kalra, N., Jacobi, J., \& Watts, C. (2013). Is early sexual debut a risk factor for HIV infection among women in Sub-Saharan Africa? A systematic review. American Journal of Reproductive Immunology, 69(Suppl. 1), 2740. https://doi.org/10.1111/aji.12043

Tenkorang, E. Y., \& Adjei, J. K. (2015). Household living arrangements and transition to sexual debut among young people in Ghana. Sex Education, 15(1), 1-18. https://doi.org/ 10.1080/14681811.2014.927356

Tuyiragize, R., Nzabona, A., Asiimwe, J. B., Kakuba, C., Mushomi, J., \& Maniragaba, F. (2018). Predisposing factors of teenage pregnancy in the Uganda Lake Victoria Island and Mountain districts. bioRxiv, 482927. https://doi.org/10.1101/482927

UNICEF. (2018). HIV epidemiology among children and adolescents 2017. UNICEF.

Violita, F., \& Hadi, E. N. (2019). Determinants of adolescent reproductive health service utilization by senior high school students in Makassar, Indonesia. BMC Public Health, 19(1), 286. https://doi.org/10.1186/s12889019-6587-6 
Jurnal Kependudukan Indonesia | Vol. 15, No. 1, Juni 2020 | 49-58

Wamoyi, J., Wight, D., \& Remes, P. (2015). The structural influence of family and parenting on young people's sexual and reproductive health in rural northern Tanzania. Culture, Health and Sexuality, 17(6), 718-732. https://doi.org/10.1080/13691058.2014.99204 4
Wiemers, E. E., Slanchev, V., McGarry, K., \& Hotz, V. J. (2017). Living arrangements of mothers and their adult children over the life course. Research on Aging, 39(1), 111-134. https://doi.org/10.1177/0164027516656138 